\title{
Analysis of flood propagation and its impact on Negeri Lima Village due to the failure of Way Ela Dam
}

\author{
Bagus Pramono Yakti ${ }^{1, *}$, Mohammad Bagus Adityawan ${ }^{1}$, Iwan Kridasantausa Hadihardaja ${ }^{1}$, Yadi Suryadi ${ }^{1}$, Joko \\ Nugroho ${ }^{1}$, and Arno Adi Kuntoro ${ }^{1}$ \\ ${ }^{1}$ Center for Water Resources Development, Institute for Research and Community Services, Institut Teknologi Bandung, Bandung, \\ Indonesia
}

\begin{abstract}
Way Ela dam is a dam to be built in the Negeri Lima village. In the negeri lima village there was also a dam that formed naturally by landslide due to high rainfall on 13 July 2012 . A year after it was formed, on 25 July 2013 flooding occurred due to an extreme rainfall that caused the failure of the natural dam. The event of the failure on 2012 generated flood that severely damaged houses and various public facilities to negeri lima village down toward to the coast. As a result of this event, a small-scale reservoir is formed. The Government plans to utilize the established reservoir to build the new Way Ela Dam. This study was conducted to analyze floods with scenarios in the event of a failure in the new Way Ela Dam. The overland flow is simulate with two dimensional numerical model HEC-RAS v.5. Determining strategies for mitigation needs to be assessed comprehensively, by simulating disaster scenarios on the dam, analyzing the impacts and then planning recommendations for disaster risk. The results are expected to be a reference for mitigation plans for the new Way Ela Dam.
\end{abstract}

\section{Introduction}

Way Ela Dam is a dam to be built in the Negeri Lima village. In the negeri lima village there was also a dam that formed naturally by landslide due to high rainfall on 13 July 2012 [1]. A year after it was formed, on 25 July 2013 flooding occurred due to an extreme rainfall that caused the failure of the natural dam. The event of the failure on 2012 generated flood that severely damaged houses and various public facilities to negeri lima village down toward to the coast. As a result of this event, a small-scale reservoir is formed.

The Government plans to utilize the established reservoir to build the new Way Ela Dam. Based on regulation in Indonesia mention that during construction of the dam, each dam must prepare a plan for emergency action [2]. This study was conducted to analyze floods due to dam break scenarios in the new Way Ela Dam which can be used as a guide or input in the preparation of emergency action plan documents.

Dam Break flows can be analyzed by analytical, numerical and experimental method. The numerical model itself has been carried out with finite difference in 1D [3] and finite volume [4]. The numerical model 1d for dam break has not been able to accurately determine the flood propagation due to the dam failure. US Crops Army's Hydrology Engineering center's River Anaylsis System (HEC-RAS) simulation model is a numerical model with a free license that has been widely used to simulate flood propagation. Starting from v.5, the model is capable for determining water depth, discharge, inundation area, and flood wave velocity \& flood arrival time in two dimensions. The model was developed based on the full 2D St. Venant equations, solved using a finite difference scheme. The model is powerful, robust and accurate. The model was applied for simulating Way Ela Natural Dam Failure [5] Ujjani Dam Break [6] and Montecello Dam Breach [7] with a good result.

In this study, the analysis of flood propagation due to dam break scenario of Way Ela Dam is conducted in order to predict the flood inundation, flood depth and flood arrival time on the negeri lima village so that it can be anticipate and reduce the human-economic losses. The modeling is based on the Probable Maximum Flood and the DEM (Digital Elevation Model) data from measurement $1 \mathrm{~m} \times 1 \mathrm{~m}$. A two-dimensional (2D) numerical model, HEC-RAS v.5.0.5, is used to simulate the overland flow. The dam break itself is simulated by using HEC-HMSv.4.2.1 with four scenarios as follows: 1) Overtopping; 2) Top Piping; 3) Middle Piping; 4) Bottom Piping.

\section{Materials and methods}

Analyzing of failure of dam in this study will be carried out in two steps. 1) Analysis of oiutflow hydrograph from

\footnotetext{
* Corresponding author: bagusyakti@gmail.com
} 
the dam break. 2) The outflow from the breach must be routed through the downstream of Way Ela Dam to determine the impact of the flood at Negeri Lima Village.

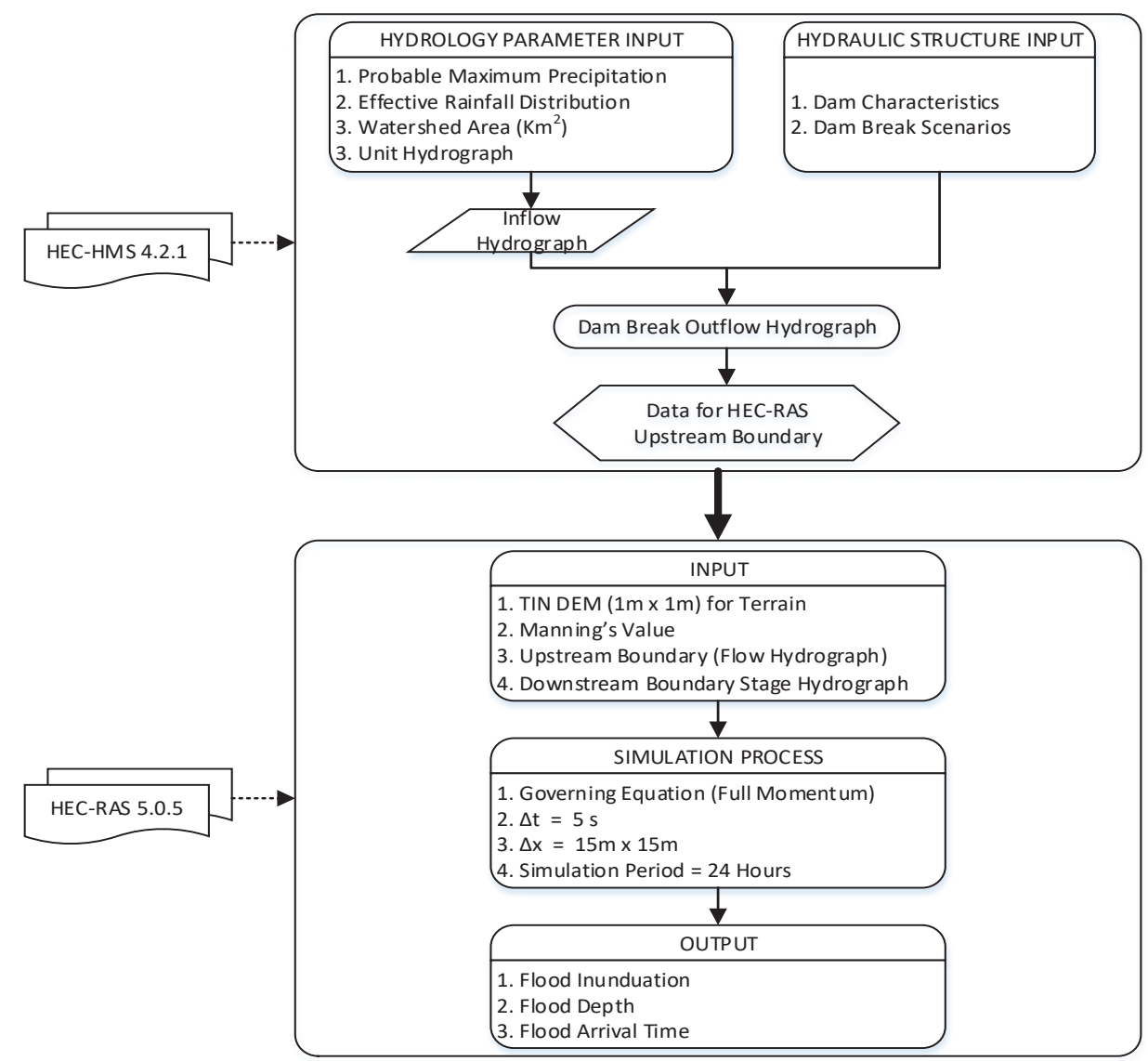

Fig.1. Scheme of methodology

\subsection{Study area}

Refer to [5] Way Ela Dam is located in Negeri Lima Village, Leihitu District, Ambon Island. The village had a mean elevation between $0-700 \mathrm{~m}$ above sea level. The main River are the Way Ela River which in 2012 dammed to form a natural dam due to avalanches.

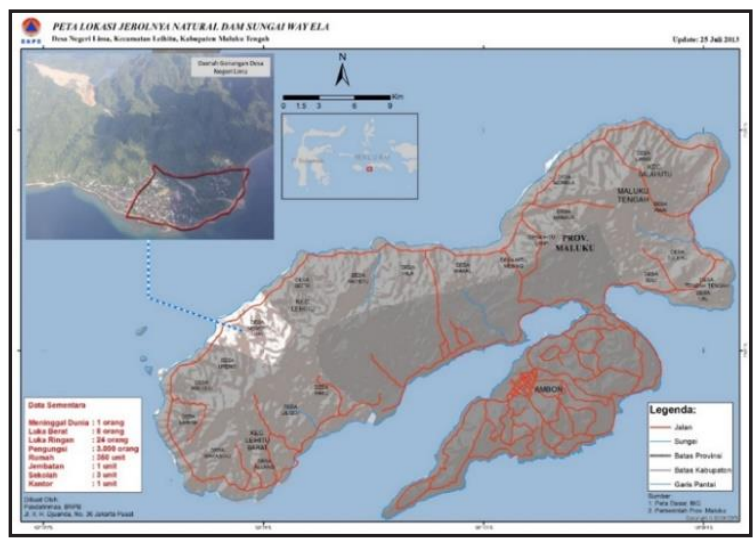

Fig. 2. Study area. BNPB [1]

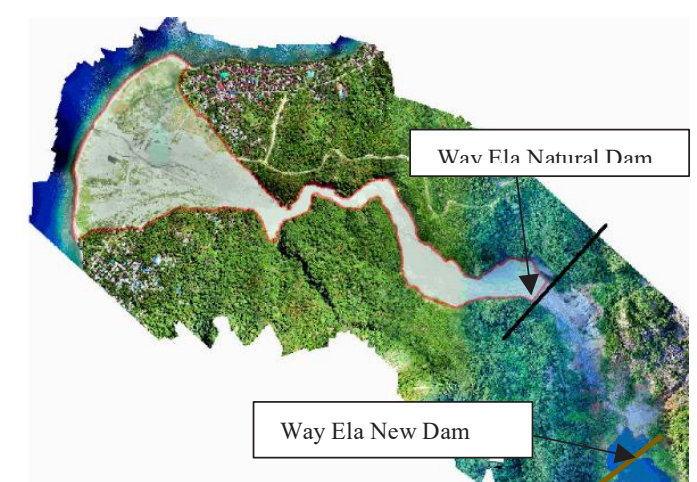

Fig. 3. Orthophoto of inunduation image after the Way Ela Natural dam failure.

\subsection{Data used}

The data collected for the study includes the daily rainfall data for the past 32 years $(1981$ - 2013) from the Indonesia Meteorological department. The Topography data for digital elevation model is based on topographic measurement. The distance between contours is $1 \mathrm{~m}$. 


\subsection{Probable maximum precipitation}

Probable maximum precipitation (PMP) is a theoretical concept that is widely used by hydrologists to arrive at estimates for probable maximum flood (PMF) that find use in planning, design and risk assessment of highhazard hydrological structures such as flood control dams upstream of populated areas. [8]

Probable Maximum Precipitation in this study is analyzed using Hersfield Method refer to [9] (SNI 77462012).

\subsection{Reservoir routing}

Reservoir routing was calculated using HEC-HMS 4.2.1 to estimate the amount of discharge when the dam failed. There are two main parameters used as the input for reservoir routing, Inflow Hydrograph from Way Ela River watershed and Hydraulic Structure of Way Ela Dam. The output from this reservoir routing is the outflow discharge due the failure of Way Ela Dam. The Inflow Hydrograph can be obtain from hydrology parameter of Way Ela watershed.

Table 1. HEC-HMS data used

\begin{tabular}{|c|c|}
\hline Data & Values \\
\hline Watershed Area $\left(\mathrm{km}^{2}\right)$ & 10.7 \\
\hline River Length $(\mathrm{km})$ & 5.1 \\
\hline Land Cover (Runoff Coefficient) & 0.5 \\
\hline Inflow Hydrograph & Figure 4 \\
\hline Dam Top Elevation $(\mathrm{m})$ & +193 \\
\hline Dam Top Length $(\mathrm{m})$ & 490 \\
\hline Normal Water Level $(\mathrm{m})$ & +190 \\
\hline
\end{tabular}

\subsubsection{Inflow}

The inflow of the reservoir was calculated using probable maximum precipitation as a design rainfall. Three unit hydrograph method is used to obtain the inflow hydrograph from Way Ela river watershed. 1) Nakayasu, 2) Snyder-Alexeyev 3) SCS. Each method is calibrate using Creager's method is a kind of estimation of specific flood and this method provided nonlinear equations based on relationship between the drainage area and PMF in order to calculate the PMF of multipurpose dams over medium-sized [10]. The characteristic of the watershed area as given in table 1 .

\subsection{Resevoir bathymetry}

Reservoir Bathymetry of the Way Ela Dam was analyzed based on topography data the result is given in figure 5 and figure 6 .

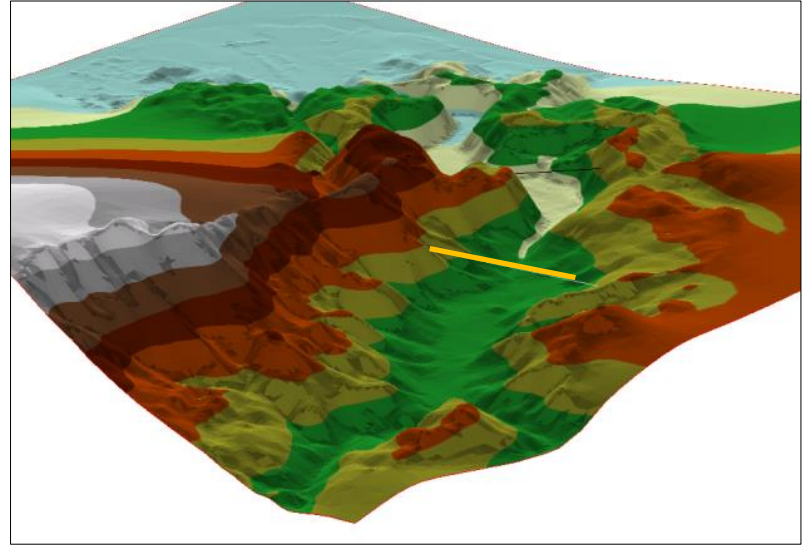

Fig. 5. 3D view at the study location afte the Way Ela Natural dam failure.

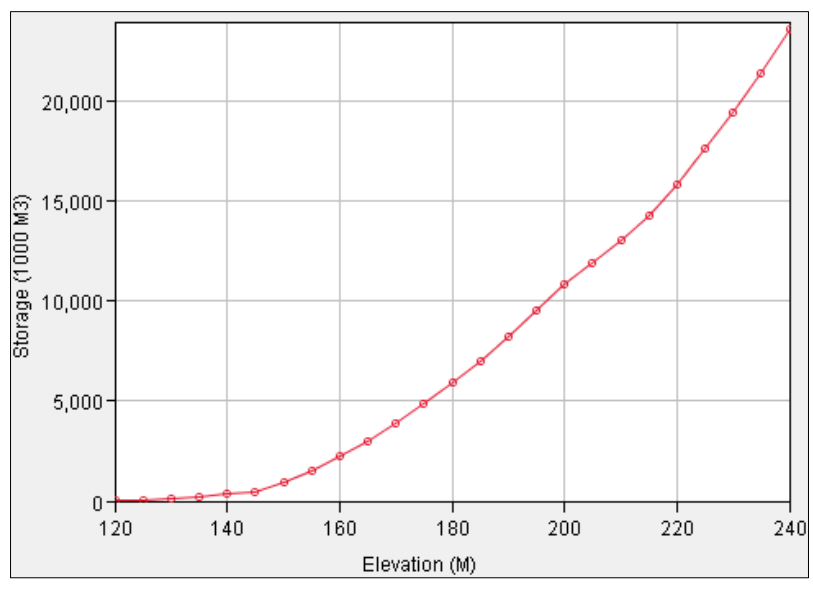

Fig. 6. Way Ela dam reservoir bathymetry

\subsubsection{Dam failure scenario}

Table 2. Dam break parameter for overtopping scenario

\begin{tabular}{|c|c|}
\hline \multicolumn{2}{|c|}{ Overtopping } \\
\hline Top Elevation (m) & 193 \\
\hline Bottom Elevation (m) & 120 \\
\hline Bottom Width & 73 \\
\hline Left Slope (xH : 1V) & 1 \\
\hline Right Slope (xH : 1V) & 1 \\
\hline Development Time (HR) & 0.5 \\
\hline Trigger Elevation (m) & 193 \\
\hline
\end{tabular}

Table 3. Dam break parameter for piping scenario

\begin{tabular}{|c|c|c|c|}
\hline \multicolumn{4}{|c|}{ Piping } \\
\hline & Top & Middle & Bottom \\
\hline Top Elevation (m) & 193 & 193 & 193 \\
\hline Bottom Elevation (m) & 120 & 120 & 120 \\
\hline Bottom Width & 73 & 73 & 73 \\
\hline Left Slope (xH : 1V) & 1 & 1 & 1 \\
\hline Right Slope (xH : 1V) & 1 & 1 & 1 \\
\hline Piping Elevation (m) & 171 & 151 & 121 \\
\hline Development Time (HR) & 0.5 & 0.5 & 0.5 \\
\hline Trigger Elevation (m) & 193 & 193 & 193 \\
\hline
\end{tabular}




\subsection{Flood propagation model}

The two dimensional flood propagation was modeled using HEC-RAS v5. The HEC-RAS v5 solves the full 2D Saint Venant equations [11] :

Continuity Equation

$$
\frac{\partial \zeta}{\partial \tau}+\frac{\partial p}{\partial x}+\frac{\partial q}{\partial y}=0
$$

Momentum Equation :

$$
\begin{aligned}
& \frac{\partial p}{\partial \tau}+\frac{\partial}{\partial x}\left(\frac{p^{2}}{h}\right)+\frac{\partial}{\partial x}\left(\frac{p q}{h}\right)= \\
& -\frac{n^{2} p g \sqrt{p^{2}+q^{2}}}{h^{2}}-g h \frac{\partial \zeta}{\partial \tau} \\
& +p f+\frac{\partial}{p \partial x}\left(h \tau_{x x}\right)+\frac{\partial}{p \partial y}\left(h \tau_{x y}\right)
\end{aligned}
$$

where $\mathrm{h}$ is the water depth (m), $\mathrm{p}$ and $\mathrm{q}$ are the specific flow in the $x$ and $y$ directions $\left(\mathrm{m}^{2} / \mathrm{s}\right)$, is the surface elevation $(\mathrm{m}), \mathrm{g}$ is the acceleration due to gravity $(\mathrm{m} / \mathrm{s}), \mathrm{n}$ is the Manning resistance, $\rho$ is the water density $\left(\mathrm{kg} / \mathrm{m}^{3}\right)$, $\mathrm{xx}$, yy and xy are the components of the effective shear stress and $f$ is the Coriolis $(1 / \mathrm{s})$. The manning roughness is estimated for each type of land cover as given in the table and figure bellow.

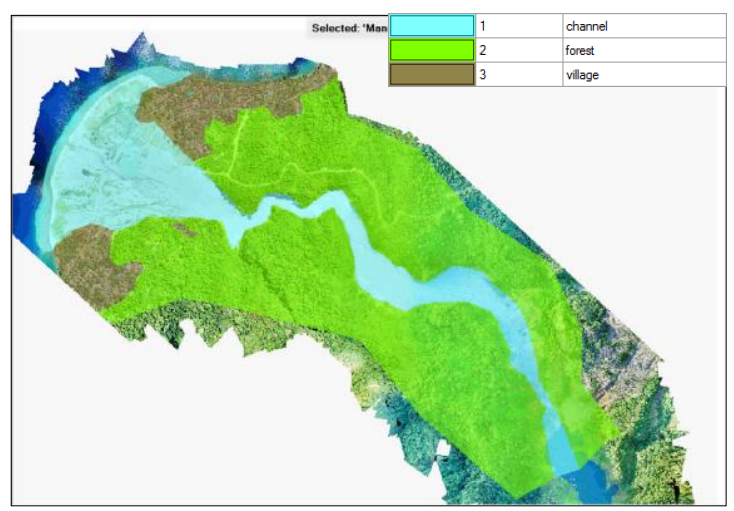

Fig. 7. Manning distribution map " $n$ "

Table 4. Manning's Roughness

\begin{tabular}{|c|c|}
\hline Land Cover & Manning's $\boldsymbol{n}$ \\
\hline Forest & 0.03 \\
\hline Channel/Coastal & 0.025 \\
\hline Village & 0.172 \\
\hline
\end{tabular}

Source : Kotani, et. al. [12], chow [13], Gibson [14]

In order to ensure the stability of the model, the time step was estimated according to the Courant-Friedrichs-Lewy condition :

$$
C r=\frac{c \Delta t}{\Delta x}=\frac{\sqrt{g h} \Delta t}{\Delta x} \leq 1
$$

Table 4. Input data for flood propagation model

\begin{tabular}{|c|c|}
\hline Data & Values \\
\hline $\begin{array}{c}\text { Outflow Hydrograph } \\
\text { (Upstream Boundary) }\end{array}$ & $\begin{array}{c}\text { From Reservoir } \\
\text { Routing }\end{array}$ \\
\hline $\begin{array}{c}\text { Stage Hydrograph } \\
\text { (Downstream Boundary) }\end{array}$ & 0 \\
\hline Terrain & $15 \mathrm{~m} \times 15 \mathrm{~m}$ \\
\hline Land Cover (manning's $n$ ) & Table 4 \\
\hline$\Delta t$ [s] & 5 \\
\hline$\Delta x[\mathrm{~m}]$ & 15 \\
\hline Simulation Period (hours) & 20 \\
\hline
\end{tabular}

\section{Results and discussions}

\begin{tabular}{|c|c|c|c|c|c|}
\hline No & Years & $\begin{array}{c}\text { Maximum } \\
\text { Precipitation } \\
(\mathrm{m})\end{array}$ & No & Tahun & $\begin{array}{c}\text { Maximum } \\
\text { Precipitation } \\
\text { (m) }\end{array}$ \\
\hline 1 & 1981 & 232 & 15 & 1995 & 179 \\
\hline 2 & 1982 & 140 & 16 & 1996 & 231 \\
\hline 3 & 1983 & 135 & 17 & 1997 & 97 \\
\hline 4 & 1984 & 431 & 18 & 1998 & 162 \\
\hline 5 & 1985 & 151 & 19 & 2004 & 130 \\
\hline 6 & 1986 & 70 & 20 & 2005 & 101 \\
\hline 7 & 1987 & 113 & 21 & 2006 & 166 \\
\hline 8 & 1988 & 455 & 22 & 2007 & 263 \\
\hline 9 & 1989 & 233 & 23 & 2008 & 170 \\
\hline 10 & 1990 & 307 & 24 & 2009 & 97 \\
\hline 11 & 1991 & 145 & 25 & 2010 & 224 \\
\hline 12 & 1992 & 106 & 26 & 2011 & 188 \\
\hline 13 & 1993 & 150 & 27 & 2012 & 360 \\
\hline 14 & 1994 & 133 & 28 & 2013 & 432 \\
\hline \multicolumn{2}{|c|}{ Average } & $=$ & \multicolumn{3}{|c|}{200.04} \\
\hline \multicolumn{2}{|l|}{ Sd } & $=$ & \multicolumn{3}{|c|}{107.23} \\
\hline \multicolumn{2}{|c|}{$\begin{array}{ll}\text { km } \\
\text { chart }\end{array}$} & $=$ & \multicolumn{3}{|c|}{12.00} \\
\hline \multicolumn{2}{|c|}{ Sn-m } & $=$ & \multicolumn{3}{|c|}{94.87} \\
\hline \multicolumn{2}{|c|}{ Xn-m } & $=$ & \multicolumn{3}{|c|}{190.59} \\
\hline \multicolumn{2}{|c|}{$\begin{array}{ll}\text { f1 } & \text { from } \\
\text { chart } & \end{array}$} & $=$ & \multicolumn{3}{|c|}{0.99} \\
\hline \multicolumn{3}{|c|}{$\begin{array}{ll}\text { f2 } \\
\text { chart }\end{array}$} & \multicolumn{3}{|c|}{1.02} \\
\hline \multicolumn{3}{|c|}{$\begin{array}{ll}\text { f3 } & \text { from } \\
\text { chart }\end{array}$} & \multicolumn{3}{|c|}{1.01} \\
\hline \multicolumn{3}{|c|}{$\begin{array}{ll}\text { f4 } \\
\text { chart }\end{array}$} & \multicolumn{3}{|c|}{.1.05 } \\
\hline \multicolumn{2}{|l|}{ Xp } & $=$ & \multicolumn{3}{|c|}{200.60} \\
\hline \multicolumn{2}{|l|}{ Sp } & $=$ & \multicolumn{3}{|c|}{113.51} \\
\hline \multicolumn{3}{|c|}{$\begin{array}{l}\text { PMP } \\
\text { Hersfield }\end{array}$} & \multicolumn{3}{|c|}{1765.84} \\
\hline
\end{tabular}

\subsection{Maximum precipitation}

The estimated of one day weighted PMP of Way Ela watershed are presented in table 5 .

Table 5. Analysis of probable maximum precipitation 


\subsection{Maximum flood (inflow)}

Inflow hydrograph of Probable Maximum Flood is analyzed used design rainfall from Probabale Maximum Precipitation. In this study analysis was carried out using three Unit Hydrograph method, which would be calibrated by the Creager's method to determine which hydrograph method would be used. Analysis for Creager's Method can be seen in table 6 .

Table 6. Analysis of Creager's method for inflow hydrograph

\begin{tabular}{|l|l|l|l|l|l|}
\hline $\begin{array}{c}\text { Unit } \\
\text { Hydrogra } \\
\text { ph } \\
\text { Method }\end{array}$ & $\begin{array}{c}\text { QPMF } \\
\text { (m3/dt) }\end{array}$ & \multicolumn{2}{|c|}{\begin{tabular}{c}
\multicolumn{2}{|c|}{ QPMF Creager for } \\
Maluku
\end{tabular}} & $\begin{array}{l}\text { Concl } \\
\text { usions }\end{array}$ \\
\hline $\begin{array}{l}\text { QPMF } \\
\text { Snyder } \\
\text { Alexeyev }\end{array}$ & 900.23 & 212.98 & - & 425.97 & $\begin{array}{l}\text { NOT } \\
\text { OK }\end{array}$ \\
\hline $\begin{array}{l}\text { QPMF } \\
\text { Nakayasu }\end{array}$ & 1077.98 & 212.98 & - & 425.97 & OK \\
\hline QPMF SCS & 406.28 & 212.98 & - & 425.97 & OK \\
\hline
\end{tabular}

Based on table 6 the SCS method is chosen, the inflow hydrograph for SCS method given in the figure 8

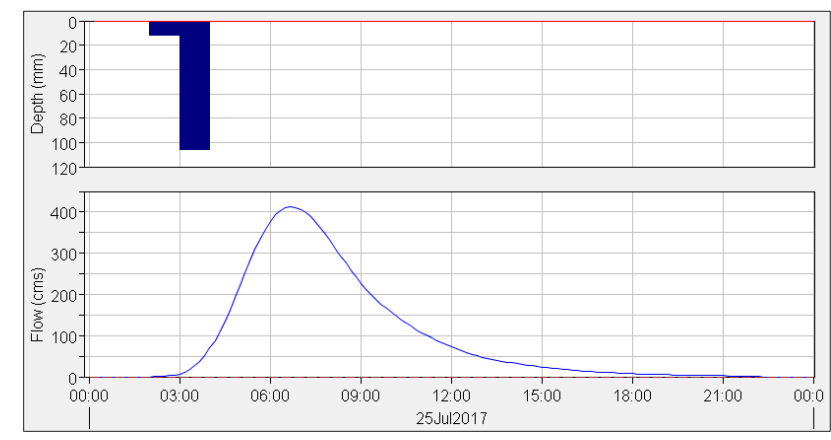

Fig. 8. QpmF SCS Inflow Hydrograph

\subsection{Reservoir routing (outflow)}

Outflow from dam failure is simulated used HEC-HMS.. Inflow Hydrograph was analyzed using the SynderAlexeyev Synthetic Unit Hydrograph. The result of this routing process will be shown by table 7 .

Table 7. Peak discharge of outflow hydrograph

\begin{tabular}{|c|c|}
\hline Dam Break Scenarios & Qpeak $\left(\mathbf{m}^{3} / \mathbf{s}\right)$ \\
\hline Overtopping & 9280.20 \\
\hline Top Piping & 13697.80 \\
\hline Middle Piping & 9319.30 \\
\hline Bottom Piping & 12429.30 \\
\hline
\end{tabular}

The outflow hydrograph for top piping dam break scenario shown by figure 9 .

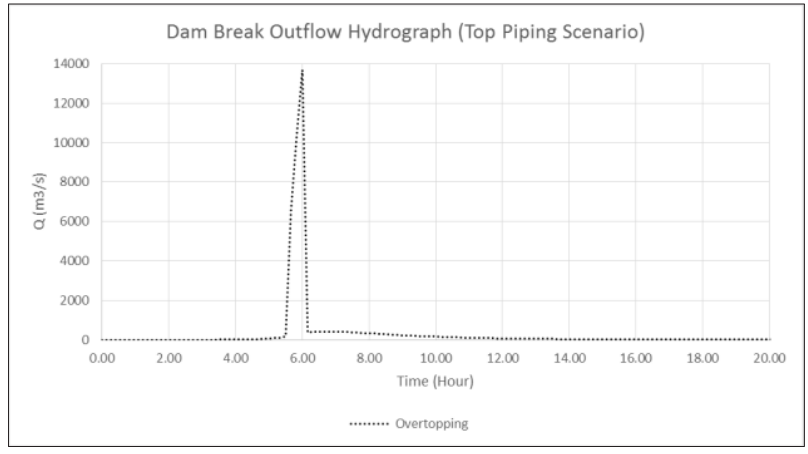

Fig. 9. Outflow hydrograph for top piping dam break

\subsection{Dam break flood propagation}

\subsubsection{Flood inundation area and depth}

Time requirement to execute this model for 1 day simulation period is 2 hours.

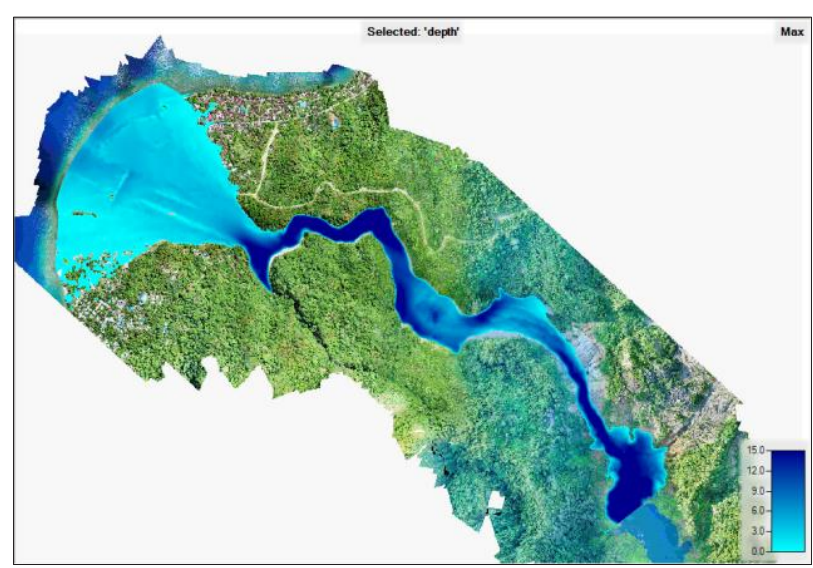

Fig. 10. Flood depth map

Figure 10 shows the maximum depth of flood inundation. The maximum depth in the village area are between 0.2 $1.5 \mathrm{~m}$, the depth of flood in the upstream near the dam is 4-20 $\mathrm{m}$, and in the middle of the channel, the depth flood inundation is quite high 4-24 $\mathrm{m}$ due to its topographic condition which is a cliff. The area of Negeri Lima Village affected by flood inundation is 2.82 ha.

\subsubsection{Flood arrival time}

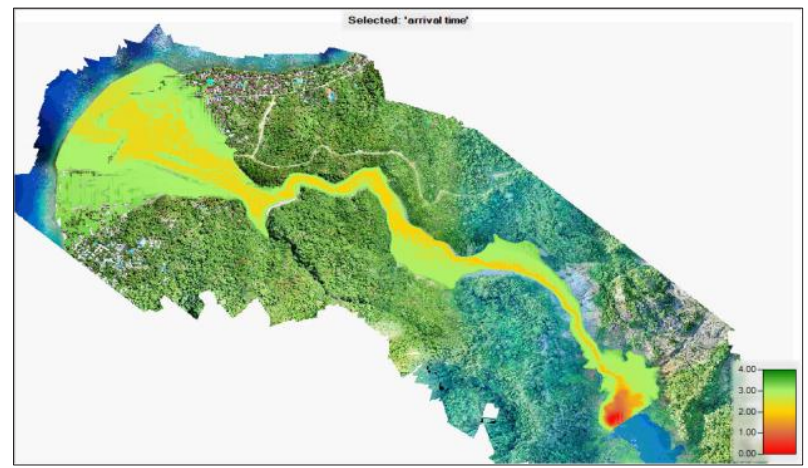

Fig. 11. Flood arrival time map 
Figure 11 shows that the arrival time of the flood caused by the dam break of Way Ela Dam it will reach the village between 2-3 hours started from the breach occured.

\section{Conclusions}

The Analysis of flood propagation due to dam break of Way Ela Dam is carried out using HEC-RAS 5.0.5 numerical model. The Probable Maximum Precipitation is found out to be $1,765.84 \mathrm{~mm}$ and the corresponding flood from the dam break flow is $13,697.80 \mathrm{~m}^{3} / \mathrm{s}$ from top piping dam break scenario. The total time of travel of dam break flood wave to Negeri Lima Village is found out to be $2-3$ hours. The flood water depth in Negeri Lima Village is up to $1.5 \mathrm{~m}$ and the area of Negeri Lima Village affected by flood inundation is 2.82 ha.

These information are very important for determining strategies for mitigation that needs to be assessed comprehensively, by simulating disaster scenarios on the dam, analyzing the impacts and then planning recommendations for disaster risk. These results are expected to be a reference for mitigation plans for the new Way Ela dam.

\section{References}

1. S.P. Nugroho, Sebagian Bendungan Way Ela di Maluku Jebol, http://www.bnpb.go.id/ (25 July 2013)

2. Minister of Public Works \& Housing Regulation No 27/PRT/M/2015

3. M. Farid, B.P. Yakti, A. Rizaldi, M.B. Adityawan, Finite Difference Numerical Scheme for Simulating Dam Break Flow, The $5^{\text {th }}$ Hathi International Seminar, Bali, (2016)

4. M.B. Adityawan, M. Roh, H. Tanaka, Dam Break Flow Simulation Using Finite Volume Method, $6^{\text {th }}$ Conference of the Asia Pacific Association of Hydrology and Water Resources, Korea, (2013)

5. B.P. Yakti, M.B. Adityawan, M. Farid. Y. Suryadi, J. Nugroho, I.K. Hadihardaja, 2D Modeling of Flood Propagation due to Failure of Way Ela Natural Dam, Matec Web Conf. 14703009 (2018).

6. M.M. Joshi, S.S. Shahapure, Two Dimensional Dam Break Flow Study Using HEC-RAS for Ujjani Dam, IJET Vol 9 No 4, 2933-2928, (2017)

7. G.W. Brunner, $2 D$ Modeling and Mapping with HEC-RAS v.5 Monticello Dam Breach. US Army Corps of Engineers, (2015).

8. S.R. Chavan, V.V. Srinivas, Probable maximum precipitation estimation for catchments in Mahanadi river basin, ICWRCOE, Aquatic Procedia 4, 892899, (2015)

9. Badan Standarisasi Nasional. SNI 7746 Tata cara penghitungan hujan maksimum boleh jadi dengan metode Hersfield, (2012)

10. A Kang, Boo-Sik \& Ryu, Seung-Yeop. Estimation of Probable Maximum Flood by Duration using Creager Method, Journal of Korean Society of Hazard Mitigation 11. 77-84. (2011).
11. V. Moya Quiroga, S. Kure, A. Mano, Application of $2 D$ numerical simulation for the analysis of the February 2014 Bolivian Amazonia flood : Application of the new HEC-RAS version 5, 36th IAHR, pp. 25-33, (2015).

12. M. Kotani, F. Imamura, and N. Shuto, JSCE 45, pp. 356-360, (1998)

13. V.T. Chow, Open-Channel Hydraulics. (McGrawHill Book Company, New York. p.113. 1959)

14. S. Gibson, Unsteady HEC-RAS Model of the Downtown Reach of the Truckee River, HEC, PR-58, 39 p., (2005) 